\title{
Effects of Individual and Combined Application of Organic Plus NPK (15:15:15) Fertilizers on the Growth Parameters of Tomato (Lycopersicon esculentum. Mill)
}

\author{
Babatunde $\mathrm{KM}^{1 \star}$, Shittu $\mathrm{KA}^{2}$, Adekanmbi $\mathrm{OA}^{1}$, and Adesina $\mathrm{A}^{1}$
}

${ }^{1}$ The oke-ogun polytechnic, department of soil science and agricultural technology, saki, oyo state, nigeria

${ }^{2}$ College of agriculture, osun state university, osogbo, nigeria

\author{
${ }^{*}$ Corresponding author \\ Babatunde KM, The oke-ogun polytechnic, department of soil science and \\ agricultural technology, saki, oyo state, Nigeria, E-mail: mbabatundekayode@ \\ gmail.com
}

Submitted: 23 Mar 2019; Accepted: 01 Apr 2019; Published: 24 Apr 2019

\begin{abstract}
Research was carried out to evaluate the effects of individual and combined application of organic, NPK (15:15:15), organic plus NPK (15:15:15), fertilizers on the growth parameters of tomato (Lycopersicon esculentum. Mill) in the greenhouse condition of The Oke - Ogun Polytechnic, Saki (Derived savannah), Oyo State, Nigeria. Study was conducted in complete randomized design (CRD). Treatments were at four levels and replicated three times. The soil used was loamy sand. Results showed that the highest average number of leaves (140), number of roots (136), root girth $(19.3 \mathrm{~cm})$ and root length $(40.8$ $\mathrm{cm})$ were achieved in organic plus NPK, highest average plant height $(78.4 \mathrm{~cm})$ and stem girth $(7.6 \mathrm{~cm})$ was achieved at 50 gm level of NPK (15:15:15) fertilizer treatment, while the highest average leaf area $(45.6 \mathrm{~cm} 2)$ was achieved at $50 \mathrm{gm}$ level of organic fertilizer, the control values were far reduced compared to other levels of treatments. The analysis of variance indicated that organic fertilizer, organic plus NPK (15:15:15) fertilizers had significant $(p \leq 0.05)$ effects on number of roots, plant height, stem girth, root girth, leaf area, root length and number of leaves. NPK (15:15:15) fertilizer had significant ( $p$ $\leq 0.05)$ effect on number of leaves, plant height and leaf area and no significant $(p \leq 0.05)$ effects on number of roots, stem girth, root girth and root length, however, $50 \mathrm{gm}$ level of treatment of organic fertilizer had distinct improved significant ( $p \leq$ $0.05)$ effects on four (4) growth parameters; number of leaves, stem girth, root girth and root length when compared with other levels of treatments for NPK (15:15:15), organic plus NPK (15:15:15) fertilizers, therefore, 50 gm level of organic fertilizer could be applied for better production of Tomato (Lycopersicon esculentum. Mill) in a loamy sand soil.
\end{abstract}

Keywords: Leaf area, Vegetable, Soil fertility, Food, Crop production

\section{Introduction}

Man needs food as one of the basic necessities of life, therefore, for Nigeria to meet up with her millennium development goal in food production, food including vegetables, must be readily available. Tomato is cultivated throughout the world [1]. Soil fertility could be a major setback for food security due to its low fertility. Successful crop production depends on soil fertility [2]. Inorganic fertilizer used to be advocated for crop production to ameliorate reduced inherent nutrient status of soils in the tropics, though, expensive and scarce, the use of inorganic fertilizer has not been helpful in intensive agriculture because it is often associated with low crop yield, soil pH and nutrient imbalance [3-5]. The need to use renewable forms of energy and low costs of fertilizing crops has revived the use of organic fertilizers across countries [6]. The crop yield response to organic waste is highly variable and depends on the types of organic wastes, crop type and species, soil type and climate conditions [7]. Furthermore, the benefits of using organic materials have not been fully utilized in the humid tropics, partly due to the huge quantities required to satisfy the nutritional needs of crops, transportation and handling costs [6]. Inorganic fertilizers, especially $\mathrm{N}, \mathrm{P}$ and $\mathrm{K}$ are the most important one which affect the crop yield [8]. Organic manure has been identified as a potential source of nutrients in vegetable production [9]. Studies have shown that the use of inorganic fertilizers in Nigeria for crops production is limited by their scarcity and high cost [10]. NPK fertilizer application had sustained soil fertility and crop production [11]. It was also reported that NPK fertilizer increased the production of various vegetables; NPK fertilizer significantly increased the height, leaf area and yield components of Okra crops [12]. Lower rates of application were also observed to increase maize yield significantly [13]. Judicious and adequate NPK fertilization combined with organic matter amendment could achieve high and sustained crop yield [14].

The objective of this study was to evaluate the effects of individual and combined application of organic, NPK and organic plus NPK $(15: 15: 15)$ fertilizers on the growth (agronomic) parameters of Tomato (Lycopersicon esculentum. Mill). 
Materials and Method

Location

The study was carried out at the greenhouse, Teaching and Research farm of the Soil Science and Agricultural Technology Department of The Oke - Ogun Polytechnic, Saki, South Western Nigeria. Average humidity, temperature and soil moisture of study area are $66 \%$, $28^{\circ} \mathrm{C}$ and $9.3 \%$ respectively during the study period ( $16^{\text {th }} \mathrm{July}$ and $21^{\text {st }}$ September, 2018). The pattern of rainfall is bimodal, with the average annual rainfall estimated to be about $1200 \mathrm{~mm}$. (The Oke Ogun Polytechnic Watch Dog weather station). The pots experiment contained 1.5 grams of the sieved soil particles and fertilizer treatments.

\section{Soil preparation and analysis}

Three core samples were taken randomly at the research locations at depth of $15 \mathrm{~cm}$ with the aid of $5 \mathrm{~cm}$ diameter metal cylinder (core sampler) for estimation of physical and chemical properties of study area soil. The soil samples was crushed after air dried and sieved to pass through $2 \mathrm{~mm}$ sieve, and analyzed. The particle size distribution was carried out using the hydrometer method described by Bouyoucos (1962) and as presented by, using $0.2 \mathrm{M}$ sodium hydroxide as dispersing agent $[15,16]$. The soil $\mathrm{pH}$ was determined using a glass electrode $\mathrm{pH}$ meter, that is; soil water suspension (1:1); organic carbon was determined using Walkley-Black method as reported by Nelson and Sommers (1982), The total nitrogen concentration was determined by macro-Kjeldahl method, and the available $\mathrm{P}$ was extracted by Bray -1 method, and determined using spectrometer $[17,18]$. Atomic absorption spectrophotometer was used to determine $\mathrm{K}, \mathrm{Ca}, \mathrm{Mg}$ and $\mathrm{Na}$ [19].

\section{Treatment}

In this research, completely randomized design (CRD) was used with four (4) treatments and in ratios where necessary and each treatment replicated thrice. The four (4) treatments as shown (Table 1, $2 \& 3$ ). The organic and the combination of organic plus NPK fertilizers were allowed for incubation period of two weeks, at the end of two weeks, all the fertilizers treatments were prepared and transplanting was done for all soil amendments. Tomato (variety - 82 - B) seeds were seeded on the $3^{\text {rd }}$ of August, 2018 in the nursery with polythene nylon and three seedlings transplanted into the experimental pots after one week of nursery care in the greenhouse. The soil treatments contained $1.5 \mathrm{~kg}$ soil in each of the experimental pot.

Fertilizer application

Table 1: Labeled of organic fertilizer

\begin{tabular}{|c|c|c|c|}
\hline O1 & O2 & O3 & O4 \\
\hline $0 \mathrm{gm}$ & $12.5 \mathrm{gm}$ & $25 \mathrm{gm}$ & $50 \mathrm{gm}$ \\
\hline $0 \mathrm{gm}$ & $12.5 \mathrm{gm}$ & $25 \mathrm{gm}$ & $50 \mathrm{gm}$ \\
\hline $0 \mathrm{gm}$ & $12.5 \mathrm{gm}$ & $25 \mathrm{gm}$ & $50 \mathrm{gm}$ \\
\hline
\end{tabular}

Table 2: Labeled of NPK (15-15-15) fertilizer

\begin{tabular}{|c|c|c|c|}
\hline $\mathbf{O 1}$ & $\mathbf{O 2}$ & $\mathbf{O 3}$ & $\mathbf{O 4}$ \\
\hline $0 \mathrm{gm}$ & $12.5 \mathrm{gm}$ & $25 \mathrm{gm}$ & $50 \mathrm{gm}$ \\
\hline $0 \mathrm{gm}$ & $12.5 \mathrm{gm}$ & $25 \mathrm{gm}$ & $50 \mathrm{gm}$ \\
\hline $0 \mathrm{gm}$ & $12.5 \mathrm{gm}$ & $25 \mathrm{gm}$ & $50 \mathrm{gm}$ \\
\hline
\end{tabular}

Table 3: Labeled of organic and NPK (15-15-15) fertilizer ratio

\begin{tabular}{|c|c|c|c|}
\hline T1 & T2 & T3 & T4 \\
\hline 0 gm:0 gm & $6.25 \mathrm{gm}: 6.25 \mathrm{gm}$ & $12.5 \mathrm{gm}: 12.5 \mathrm{gm}$ & $25 \mathrm{gm}: 25 \mathrm{gm}$ \\
\hline 0 gm:0 gm & $6.25 \mathrm{gm}: 6.25 \mathrm{gm}$ & $12.5 \mathrm{gm}: 12.5 \mathrm{gm}$ & $25 \mathrm{gm}: 25 \mathrm{gm}$ \\
\hline 0 gm:0 gm & $6.25 \mathrm{gm}: 6.25 \mathrm{gm}$ & $12.5 \mathrm{gm}: 12.5 \mathrm{gm}$ & $25 \mathrm{gm}: 25 \mathrm{gm}$ \\
\hline
\end{tabular}

\section{Growth parameters}

Growth parameters of Tomato were measured from the pots; plant height $(\mathrm{cm})$ stem girth $(\mathrm{cm})$, number of leaves, leaf area index $\left(\mathrm{cm}^{2}\right)$, root length $(\mathrm{cm})$, root girth $(\mathrm{cm})$, numbers of roots at the end of the experiment ( 8 weeks). The taller plant from each plot was selected for plant height measurement which was measured from the soil level to tip of the plant with a meter rule; also the root length was measured with a meter rule. Determination of leaf area Index (LA1) was carried out on the sampled plant. The length of the first, middle and last leaf was measured and their averages used for calculation of leaf area Index. The relationship LA $1=\mathrm{LxWxNx} 0.72 / \mathrm{A}$ where $\mathrm{L}=$ Length of leaf, $\mathrm{W}=$ Width of leaf, $\mathrm{N}=$ Number of leaves per plant, $\mathrm{A}=$ Area covered per plant, $0.72=$ constant for the determination of leaf area index (Watson et al., 2006). The number of leaves and number of roots was simply counted, while the stem girth and the root girth was measured by measuring the stem and root close to the ground and soil level with Vernier caliper respectively.

\section{Statistical analysis}

Data collected from the field were subjected to ANOVA using Minitab 16.0 and Least Significant Different (LSD) to separate the means effects of the application of organic, NPK (15-15-15) and combination of organic plus NPK (15-15-15) fertilizers on the growth parameters of Tomato.

\section{Results and Discussion}

The physical and chemical properties of the used soil (Table 4) indicated that the soil was slightly acidic (6.2) which indicated presence of nutrients, but their availability to plants depended on soil chemistry, moisture, plant type, nutrients transformations and age. According to Marinari et al. (2006), slight acidic (6.1 - 6.5) is the optimal range of $\mathrm{pH}$ for most crops, highest in magnesium $(2.68 \mathrm{~mol} /$ $\mathrm{kg})$ and least in potassium $(0.36 \mathrm{~mol} / \mathrm{kg})$, particle size distribution showed a loamy sand soil (sand $800 \mathrm{~g} / \mathrm{kg}$, clay $92 \mathrm{~g} / \mathrm{kg}$, silt $108 \mathrm{~g} /$ $\mathrm{kg}$ ) [20]. Table 5 indicated the composition of the organic fertilizer used as indicated on the labeled bag of the fertilizer; Nitrogen ( 8 $\%)$ was the highest and potassium (1.5\%) least.

Table 4: Physical and chemical properties of soil used

\begin{tabular}{|l|c|}
\hline Parameter & Value \\
\hline $\mathrm{pH}$ & 6.20 \\
\hline Available Phosphorus $(\mathrm{mg} / \mathrm{kg})$ & 3.90 \\
\hline Organic Carbon $(\mathrm{g} / \mathrm{kg})$ & 5.30 \\
\hline Organic Matter $(\mathrm{g} / \mathrm{kg})$ & 9.10 \\
\hline Total Nitrogen $(\mathrm{g} / \mathrm{kg})$ & 0.50 \\
\hline Exchangeable bases $(\mathrm{mol} / \mathrm{kg})$ & \\
\hline $\mathrm{Na}$ & 0.59 \\
\hline $\mathrm{K}$ & 0.35 \\
\hline $\mathrm{Ca}$ & 0.92 \\
\hline $\mathrm{Mg}$ & 2.68 \\
\hline
\end{tabular}




\begin{tabular}{|l|c|}
\hline Particle size distribution $(\mathrm{g} / \mathrm{kg})$ & \\
\hline Sand & 800 \\
\hline Silt & 108 \\
\hline Clay & 92 \\
\hline Textural class & Loamy sand \\
\hline
\end{tabular}

Table 5: Composition of the organic fertilizer used

\begin{tabular}{|l|c|}
\hline Composition & \% \\
\hline Nitrogen & 8.0 \\
\hline Phosphorous & 3.5 \\
\hline Potassium & 1.5 \\
\hline
\end{tabular}

Table 6 presented the effects of organic, NPK and organic plus NPK fertilizer on seven (7) growth parameters (number of leaves, number of roots, plant height, stem girth, root girth, leaf area and root length) of tomato. The average number of leaves (17) increased from control to Forty leaves (40) at $\mathrm{O} 4$ level of treatment of organic fertilizer. The control (N1) of NPK fertilizer had eighteen (18) leaves and increased to seventy five (75) leaves at N4 level of NPK treatment, however, the control level of organic plus NPK fertilizer had twenty (20) leaves and this was increased to one hundred and forty (140) leaves at T4 level of treatment. The least average number of leaves (17) was at control level of organic fertilizer treatment, while the highest average number of leaves (140) was achieved at T4 level of organic plus NPK fertilizer. The increased in number of leaves can be attributed to be influenced by $\mathrm{N}$ supply in fertilizer applied, also nutrient availability especially nitrogen $(\mathrm{N})$ determined plant vegetative development and changes in the number of leaves could affect the overall performance of the plant as the leaves serve as light receptor in photosynthesis for the manufacture of food substances $[21,22]$.

Table 6: +Effects of Organic, NPK (15-15-15), Organic plus NPK (15-15-15) fertilizers on the growth parameters of Tomato

\begin{tabular}{|c|c|c|c|c|c|c|c|c|c|c|c|c|}
\hline & \multicolumn{4}{|c|}{ Organic fertilizer } & \multicolumn{4}{|c|}{ NPK fertilizer (N) } & \multicolumn{4}{|c|}{ Organic + NPK fertilizer $(\mathrm{T})$} \\
\hline & 01 & $\mathbf{O 2}$ & $\mathbf{O 3}$ & O4 & N1 & $\mathbf{N} 2$ & N3 & N4 & T1 & $\mathbf{T} 2$ & T3 & T4 \\
\hline NL & 17 & 26 & 31 & 40 & 18 & 69 & 64 & 75 & 20 & 130 & 135 & 140 \\
\hline NR & 66 & 103 & 100 & 95 & 62 & 68 & 80 & 86 & 61 & 120 & 136 & 124 \\
\hline $\mathrm{PH}$ & 15.3 & 23.5 & 23.8 & 22.8 & 19.6 & 73.4 & 74.0 & 78.4 & 20.4 & 70.6 & 73.2 & 74.2 \\
\hline SG & 2.7 & 3.0 & 3.9 & 4.5 & 3.2 & 6.9 & 6.9 & 7.6 & 3.3 & 5.3 & 6 & 7.3 \\
\hline $\mathrm{RG}$ & 10.9 & 16.7 & 14.6 & 18.6 & 11.1 & 10.8 & 10.8 & 10.5 & 14.2 & 19.3 & 18.8 & 23 \\
\hline LA & 28.5 & 32.7 & 40 & 45.6 & 20.1 & 25 & 25.9 & 29.6 & 26.5 & 31.0 & 41.8 & 44.7 \\
\hline RL & 23 & 27.3 & 28.4 & 39.3 & 23.4 & 29.8 & 30.9 & 30.3 & 20.9 & 39.4 & 38.2 & 40.8 \\
\hline
\end{tabular}

Keys: $+=$ average of three replicates, $\mathrm{NL}=$ number of leaves, $\mathrm{NR}=$ number of roots, $\mathrm{PH}=$ plant height, $\mathrm{SG}=\mathrm{stem}$ girth, $\mathrm{RG}=$ root girth, LA = leaf area, RL = root length, O1-O4 = levels of organic fertilizer, N1-N4 = levels of NPK fertilizer, T1-T4 = levels of organic plus NPK fertilizer.

The number of roots of the effect of organic fertilizer increased from control (66) to $95(\mathrm{O} 4), 100(\mathrm{O} 3)$ and $103(\mathrm{O} 2)$. Increased number of roots was also observed due to the effect of NPK fertilizer from control (62) to 86 (N4). Organic plus NPK fertilizer combination increased the number of roots from control (61) to 120 (T2), 124 (T4) and 136 (T3). The control level of organic fertilizer treatment recorded the least average number of roots (66) and the highest average number of roots (136) was observed at T3 level of treatment of organic plus NPK fertilizer.

Organic fertilizer increased the plant height of tomato from control $(15.3 \mathrm{~cm})$ to $22.8 \mathrm{~cm}(\mathrm{O} 4), 23.5 \mathrm{~cm}(\mathrm{O} 2)$ and $23.8 \mathrm{~cm}(\mathrm{O} 3)$, however, the increased due to the effect of NPK fertilizer was from control $(19.6 \mathrm{~cm})$ to $78.4 \mathrm{~cm}(\mathrm{~N} 4)$, similar results were observed by Elbehri et al., (1993), who reported increased Amaranths' plant height at higher nitrogen application rate, also there was an increased effect due to organic plus NPK fertilizer combination on the plant height of tomato from control $(20.4 \mathrm{~cm})$ to $74.2 \mathrm{~cm}$ (T4). The least average plant height $(15.3 \mathrm{~cm})$ was observed at control level of organic fertilizer treatment, while the highest average plant height $(78.4 \mathrm{~cm})$ was achieved at N4 level of NPK fertilizer treatment.

The stem girth of tomato increased from control $(2.7 \mathrm{~cm})$ to 4.5 $\mathrm{cm}(\mathrm{O} 4)$ due to the effect of organic fertilizer, increased was also observed from control $(3.2 \mathrm{~cm})$ to $7.6 \mathrm{~cm}(\mathrm{O} 4)$, however, treatment
N2 and N3 had the same stem girth $(6.9 \mathrm{~cm})$ as a result of NPK fertilizer amendment, the combination of organic and NPK fertilizer increased the stem girth from control $(3.3 \mathrm{~cm})$ to $7.3 \mathrm{~cm}$ (T4). The least average stem girt $(2.7 \mathrm{~cm})$ was at control level of organic fertilizer treatment, while the highest average stem girth $(7.6 \mathrm{~cm})$ was achieved at N4 level of NPK fertilizer.

The root girth of tomato followed the same trend as the stem girth due to the effect of NPK fertilizer at N2 and N3; had the same root girth $(10.8 \mathrm{~cm})$ and $\mathrm{N} 4$ had the least root girth $(10.5 \mathrm{~cm})$, organic fertilizer only increased the root girth of tomato from control (10.9 $\mathrm{cm})$ to $16.7 \mathrm{~cm}(\mathrm{O} 2)$, decreased to $14.6 \mathrm{~cm}(\mathrm{O} 3)$ and increased to 18.6 $\mathrm{cm}(\mathrm{O} 4)$, this pattern of organic fertilizer effect was also observed with the organic plus NPK fertilizer where there was an increased from control $(14.2 \mathrm{~cm})$ to $19.3 \mathrm{~cm}$ (T2) decreased to $18.8 \mathrm{~cm}$ (T3) and increased at T4 level of treatment to $23 \mathrm{~cm}$. The control level of organic fertilizer treatment recorded the least average root girth $(10.9 \mathrm{~cm})$ and the highest average root girth $(19.3 \mathrm{~cm})$ was observed at T2 level of treatment of organic plus NPK fertilizer.

The leaf area indicated a gradual increased from control $\left(20.1 \mathrm{~cm}^{2}\right)$ to $29.6 \mathrm{~cm}^{2}$ (N4) due to the effect of NPK fertilizer, the organic fertilizer increased the leaf area of tomato from control $\left(28.5 \mathrm{~cm}^{2}\right)$ to $45.6 \mathrm{~cm}^{2}(\mathrm{O} 4)$, while increased from control $\left(26.5 \mathrm{~cm}^{2}\right)$ to $44.7 \mathrm{~cm} 2$ (T4) was achieved due to the effect of organic plus NPK fertilizer. 
The least average leaf area $\left(20.1 \mathrm{~cm}^{2}\right)$ was at control level of NPK fertilizer treatment, while the highest average leaf area $\left(45.6 \mathrm{~cm}^{2}\right)$ was achieved at $\mathrm{O} 4$ level of organic fertilizer. Richert and Salomon (2012) reported an increased leaf area of lettuce and cabbage crops when chicken manure was used as organic fertilizer.

The root length increased from control $(23 \mathrm{~cm})$ to $39.3(\mathrm{O} 4)$ due to organic fertilizer effect, NPK fertilizer only increased the root length of tomato from the control $(23.4 \mathrm{~cm})$ to $30.9 \mathrm{~cm}(\mathrm{~N} 3)$, but the increased from control (20.9) $\mathrm{cm}$ to $40.8 \mathrm{~cm}$ (T4) was due to the combination of organic plus NPK fertilizer. The least average root length $(20.9 \mathrm{~cm})$ was observed at control level of organic plus NPK fertilizer treatment, while the highest average root length $(40.8 \mathrm{~cm})$ was achieved at T4 level of organic plus NPK fertilizer treatment, however, better performance of maize, cassava and melon under poultry manure + NPK fertilizer and the trend observed was NPK fertilizer + poultry manure $>$ NPK fertilizer $>$ poultry manure $>$ no fertilizer (Ayoola \& Adeniyan, 2006).

The analysis of variance of treatments of effects of organic, NPK and organic plus NPK fertilizers on the growth parameters of tomato (Table 7) indicated that organic fertilizer had significant $(p \leq 0.01)$ effects on number of roots, plant height, stem girth, root girth, leaf area and root length and significant $(\mathrm{p} \leq 0.05)$ effect on the number of leaves. These findings are consistent with the findings of Aduloju et al., (2010) and Dada \& Fayinminnu (2010) who reported that nutrients from mineralization of organic matter promote growth performance. NPK fertilizer had significant $(\mathrm{p} \leq 0.01)$ effect on number of leaves, significant $(\mathrm{p} \leq 0.05)$ effects on plant height and leaf area and no significant $(\mathrm{p} \leq 0.05)$ effects on number of roots, stem girth, root girth and root length, similar results was reported by Babatunde et al., (2016). Organic plus NPK fertilizer effect on the growth parameters of tomato followed the same trend as the organic fertilizer only, but the effects of organic plus NPK were more pronounced as indicated by the mean squares in ANOVA table (Table 7). Significant $(p \leq 0.01)$ effects was observed on number of roots, plant height, stem girth, root girth, leaf area and root length, however, significant $(\mathrm{p} \leq 0.05)$ effect was achieved on number of leaves due to the effects of organic fertilizer only and organic plus NPK fertilizers . The root length was significantly enhanced due to increased supply rate of organic plus NPK fertilizer. Similar results were reported by Tolera et al. (2018), observed that maximum root growth and rooting depth of barley crop were higher in treatments which received organic and inorganic fertilizer relative to the control.

Least significant difference $(\mathrm{p}=0.05)$ of the means of treatments were separated (Table 8), indicated that O4 level of treatment of the organic fertilizer had pronounced significant $(\mathrm{p}=0.05)$ effects on five (5) growth parameters (number of leaves, stem girth, root girth, leaf area and root length), but T2 had increased significant ( $p$ $=0.05$ ) effect on number of roots only. T4 level of NPK fertilizer treatment (Table 8$)$ had increased significant $(p=0.05)$ effects on number of leaves and leaf area. T3 level of organic plus NPK fertilizer had pronounced significant $(p=0.05)$ effects on number of roots, stem girth and leaf area, while T4 and T2 had significant ( $\mathrm{p}=$ 0.05 ) increased effect on the root girth and plant height respectively.

Table 7: +Mean square of analysis of variance of treatments of effects of Organic, NPK (15-15-15), Organic plus NPK (15-15-15) fertilizers on the growth parameters of Tomato

\begin{tabular}{|l|c|c|c|c|c|c|c|}
\hline Fertilizer treatment & Number of Leaves & Number of Roots & Plant Height & Stem Girth & Root Girth & Leaf Area & Root Length \\
\hline Organic & $285.0^{* *}$ & $888.2^{*}$ & $49.23^{*}$ & $2.07^{*}$ & $32.01^{*}$ & $173.03^{*}$ & $104.13^{*}$ \\
\hline NPK & $80.6^{*}$ & $364 \mathrm{~ns}$ & $210.6^{* *}$ & $1.1 \mathrm{~ns}$ & $0.18 \mathrm{~ns}$ & $68.9^{* *}$ & $6.17 \mathrm{~ns}$ \\
\hline Organic + Inorganic & $164.2^{* *}$ & $892.6^{*}$ & $312.7^{*}$ & $8.7^{*}$ & $39.33^{*}$ & $223.6^{*}$ & $261.7^{*}$ \\
\hline
\end{tabular}

*significant at $\mathrm{p} \leq 0.01$

$* *$ significant at $\mathrm{p} \leq 0.05$

$\mathrm{ns}=$ not significant

$+=$ average of three replicates.

Table 8: LSD of Organic, NPK (15-15-15), Organic plus NPK (15-15-15) fertilizers on the growth parameters of Tomato

\begin{tabular}{|c|c|c|c|c|c|c|c|}
\hline $\begin{array}{l}\text { Fertilizer } \\
\text { treatment }\end{array}$ & $\begin{array}{c}\text { Number of } \\
\text { leaves (means) }\end{array}$ & $\begin{array}{c}\text { Number of root } \\
\text { (means) }\end{array}$ & $\begin{array}{c}\text { Plant height } \\
\text { (means) }\end{array}$ & $\begin{array}{r}\text { Stem girth } \\
\text { (means) }\end{array}$ & $\begin{array}{r}\text { Root girth } \\
\text { (means) }\end{array}$ & $\begin{array}{c}\text { Leaf } \\
\text { area (means) }\end{array}$ & $\begin{array}{r}\text { Root length } \\
\text { (means) }\end{array}$ \\
\hline \multirow[t]{4}{*}{ Organic } & $\mathrm{T} 4$ 40a & T2 103a & T3 $23.8 \mathrm{a}$ & $\mathrm{T} 44.5 \mathrm{a}$ & T4 18.6a & T4 45.6a & T4 39.3a \\
\hline & T3 31b & T3 100ab & T2 23.5a & T3 $3.9 b$ & $\mathrm{~T} 216.7 \mathrm{~b}$ & T3 40a & T3 28.4b \\
\hline & $\mathrm{T} 226 \mathrm{~b}$ & T4 95b & T4 22.8a & $\mathrm{T} 23.0 \mathrm{c}$ & T3 $14.6 \mathrm{c}$ & $\mathrm{T} 232.7 \mathrm{~b}$ & $\mathrm{~T} 227.3 \mathrm{~b}$ \\
\hline & T1 17c & T1 66c & T1 $15.3 \mathrm{~b}$ & $\mathrm{~T} 12.7 \mathrm{c}$ & T1 10.9d & T1 $28.5 b$ & T1 23b \\
\hline \multirow[t]{4}{*}{ NPK } & T4 75a & ns & $\mathrm{T} 478.4 \mathrm{a}$ & ns & ns & T4 29.6a & $\mathrm{ns}$ \\
\hline & T2 $69 \mathrm{~b}$ & ns & T3 74a & ns & ns & T3 25.9b & $\mathrm{ns}$ \\
\hline & T3 64b & ns & $\mathrm{T} 273.4 \mathrm{a}$ & ns & ns & $\mathrm{T} 225.0 \mathrm{~b}$ & ns \\
\hline & T1 18c & ns & T1 19.6b & ns & ns & T1 20.1b & ns \\
\hline \multirow{4}{*}{$\begin{array}{l}\text { Organic }+ \\
\text { NPK }\end{array}$} & T4 140a & T3 136a & $\mathrm{T} 474.2 \mathrm{a}$ & $\mathrm{T} 4$ 7.3a & T4 23a & $\mathrm{T} 444.7 \mathrm{a}$ & $\mathrm{T} 440.8 \mathrm{a}$ \\
\hline & T3 135a & T4 124b & T3 73.2a & T3 6.3b & $\mathrm{T} 219.3 \mathrm{~b}$ & T3 41.8a & T2 39.4a \\
\hline & T2 132a & $\mathrm{T} 2120 \mathrm{~b}$ & $\mathrm{~T} 270.6 \mathrm{~b}$ & $\mathrm{~T} 25.3 \mathrm{c}$ & $\mathrm{T} 318.8 \mathrm{~b}$ & $\mathrm{~T} 231.0 \mathrm{~b}$ & T3 $38.2 \mathrm{a}$ \\
\hline & $\mathrm{T} 1 \mathrm{122b}$ & T1 61c & T1 20.4c & $\mathrm{T} 13.3 \mathrm{~d}$ & $\mathrm{~T} 1 \mathrm{14.2 \textrm {c }}$ & $\mathrm{T} 126.5 \mathrm{~b}$ & T1 20.9b \\
\hline
\end{tabular}


Mean followed with different alphabet within the column differs significantly at $\mathrm{p}=0.05$

\section{Conclusion}

Generally, organic fertilizer and organic plus NPK fertilizers had significant $(\mathrm{p} \leq 0.05)$ effects on all the growth parameters of tomato, while NPK fertilizer only had significant $(p \leq 0.05)$ effects on number of leaves, plant height and leaf area (Table 7). O4 level of treatment of organic fertilizer had distinct pronounced significant $(p=0.05)$ effects on four (4) growth parameters; number of leaves, stem girth, root girth and root length. T4 level of NPK fertilizer had distinct significant $(p=0.05)$ effects on two (2) growth parameters; number of leaves and leaf area. Organic plus NPK fertilizer at different levels of treatment had distinct significant $(\mathrm{p}=0.05)$ effects on four $(4)$ growth parameters; number of roots (T3), plant height (T2), and T4 (stem girth and root girth) (Table 8), therefore, $\mathrm{O} 4$ level of organic fertilizer could be applied for better production of tomato in a loamy sand soil.

\section{References}

1. Oyen LPA, Lemmens RH (2002) RN Leister, and A Seck, Solanum aethiopicum L. Record from protobase. PROTA (Plant Resources of Tropical Africa/ Resources Vegetables.

2. Mbah CN (2006) Influence of organic wastes on plant growth parameters and nutrient uptake by maize (Zea mays L.). Nigerian Journal of Soil Science 16: 104-108.

3. Ojeniyi SO (2000) Effect of goat manure on soil nutrients and okra yield in a rainforest area of Nigeria. Applied Tropical Agriculture 5: 20-23.

4. Ano AO, Agwu JA(2005) Effect of animal manures on selected soil chemical properties. Nigerian Journal of Soil Science 15: 14-19.

5. Agbede TM, Ojeniyi SO, Adeyemo AJ (2008) Effect of poultry manure on soil physical and chemical properties, growth and grain yield of sorghum in southwest Nigeria. American-Eurasian Journal of Sustainable Agriculture 2: 72-77.

6. Ayoola OT, Adeniyan ON (2006) Influence of NPK fertilizer on yield and yield components of crops under different cropping systems in south west Nigeria. African Journal of Biotechnology 5: 1386-1392.

7. Adediran JA, Taiwo LB, Sobulo RA(2003) Comparative nutrient values of some solid organic wastes and their effect on tomato (Lycopersicon esculentum) yield. African Soils 33: 99-113.

8. Simon JH, Sobulo RA (1974) Methods for higher tomato yield in Western State of Nigerian. Paper presented at Institute of Agric. research Conference. Ibadan, Nigeria, Sparks DL (ed) (1996) Methods of Soil Analysis: chemical methods. Part 3. Soil Science Society of America. Book Series No.5. ASA-SSSA, Madison, WI 869-920.

9. Ehigiator JO (1998) Farm yard manure; needs for its adoption as an alternative to chemical fertilizers uses in Nigeria. Nigerian Journal of Horticultural Science 3: 19.

10. Akanbi WB, Togun AO, Baiyewu RA (2001) Suitability of plant residue compost as nursery growing medium for some tropical fruit tree Seedlings. Moor Journal of Agricultural Research 2: 41-45.

11. Uyovbisere EO, Chude VO, Bationo A (2000) Promising nutrient ratios in fertilizer formulations for optimal performance of maize in the Nigerian savanna. The need for a review. Nigeria Journal of Soil Research 1: 29-34.

12. Nadaeyo NU, Ukpong ES, John NM (2005) Performances of okra as affected by organic and inorganic fertilizers on an ultisol. Proceedings of the 39th conference of the Agricultural Society of Nigeria, Benin City 206-208.
13. Odedina SA (2005) Evaluation of NPK rate combinations for maize production in humid zones of Nigeria. Nigeria Journal of Soil Science 15: 111-115.

14. Osundare B (2004) Effects of fertilizer types and varying population on the performance of cocoyam. Moor Journal of Agricultural Research 5: 7-12.

15. Bouyoucous GH (1962) Hydrometer Method Improved for Making Particle Size Analysis of Soils. Agronomy Journal 54: 464-465.

16. Gee GW, Or BD (2002) Particle size analysis. In: J H dane and GC Topp (eds). Methods of soil analysis part 4: 255-293.

17. Nelson DW, Sommers LE (1982) Total carbon and organic matter. A. L Page et al. (ed). Methods of Soil analysis.Part 2 ( $2^{\text {nd }}$ ed.), American Society of Agronomy. Madison, USA.

18. Bremner JM (1996) Total Nitrogen. In: Sparks, DL, Ed, Methods of Soil Analysis, Part 3, Chemical Methods, SSSA and ASA, Madison 1123-1184.

19. Okalebo JR, Gathua KW, Woomer P (2002) Laboratory Methods of Soil and Plant Analysis: A Working Manual. ${ }^{\text {nd }}$ Edn. TSBFCIAT, Nairobi, Kenya, Pagers: 126.

20. Marinari SR, Mancinelli EC, Grego S (2006) Chemical and biological indicators of soil quality in organic and conventional farming systems in Central Italy. Ecological Indicators 6: 701-711.

21. Ehigiator JO (1990) Farm yard manure: Need for its adoption as an alternative to chemical fertilizer uses in Nigeria. Nigerian Journal of Horticultural Science 3: 1-9.20.

22. Gungula DT (1999) Growth and Nitrogen use efficiency in maize (Zea mays L) in the Southern Guinea Savanna of Nigeria. $\mathrm{Ph}$. D Thesis, Univ. of Ibadan 181.

23. Elbehri AD, Putnam H, Schmitt M (1993) Nitrogen fertilizer emergence in wheat and barley. Crop Science 31: 1218-1224.

24. Richert AS, Salomon S (2012) Application of broiler chicken manure to lettuce and cabbage crops: effect on yield, plant utilization and mineral nitrogen in the soil. Act Horticulture 571: 10-12.

25. Aduloju MO, Fawole OB, Abubakar AJ, Olaniyan JO (2010) Effect of sawmill wastes, animal manure and NPK fertilizer on the performance of okra (Abelmoschus esculentus L. Moench) on an Alfisol. Department of Agronomy, University of Ilorin, Nigeria.

26. Dada OA Fayinminnu OO (2010) Period of weed control in Okra [Abelmoschus esculentus (L.) Moench] as influenced by varying rates of cattle dung and weeding regimes. Notulae Botaanicae Horti Agrobotanicicluj-Napoca, 38: 149-154. Direct Link (http://notulaebotanicae.ro/index.php/nbha/article/ download/3676/4434)

27. Babatunde KM, Adekanmbi OA, Adeyolanu AS, Salau MA (2016) Effects of Varying Tillage Passes and 15-15-15 NPK Fertilizer on Some Agronomic Parameters, Nitrogen, Phosphorous and Potassium Uptake by Amaranthus viridis in Derived Savannah of Southwest Nigeria. Journal of Horticulture 3: 179.

28. Tolera A, Tolcha T, Tesfaye M, Haji K, Buzuayehu T (2018) Effect of Integrated Inorganic and Organic Fertilizers on Yield and Yield Components of Barley in Liben Jawi District," International Journal of Agronomy 2018: 1-7.

Copyright: (c)2019 Babatunde KM. This is an open-access article distributed under the terms of the Creative Commons Attribution License, which permits unrestricted use, distribution, and reproduction in any medium, provided the original author and source are credited. 